\title{
Assesment of Fish Products Demand in Buryatia, Russia
}

\author{
Anna P. Nikiforova \\ PhD in Technical Sciences, Senior Lecturer, East Siberia State University of Technology and Management
}

Olga P. Nikiforova

PhD in Economics, Senior Lecturer, Ulaanbaatar branch of Plekhanov Russian University of Economics

Inna V. Antokhonova

Doctor of Economics, Professor, East Siberia State University of Technology and Management

Doi:10.5901/mjss.2016.v7n3p118

\begin{abstract}
The article is devoted to analysis of fish products consumption in the Republic of Buryatia. The objective of the study was to identify patterns of consumption of fish and fish products in Buryatia through cluster analysis and investigate associations with sociodemographic variables. The participants were a sample of citizens of city of Ulan-Ude. A survey was performed to heads of households $(N=150)$. In the study hierarchical cluster analysis with the Ward's method was used for segmentation of market. Cluster profiles were achieved by comparing mean values on the dimensions for each segment with population mean values on the same dimensions. Five distinct cluster groupings were found.
\end{abstract}

Keywords: cluster analysis, Buryatia, fish products, food behavior, consumption

\section{Introduction}

The consumption of fish and fish products in Russian Federation can be characterized by tendency of growth. Growth rate of fish consumption exceeds growth rate of other food products. Fish market could be categorized as reliable food market. Average fish consumption in Russian Federation is about $20 \mathrm{~kg}$ per capita, that is significantly lower than in developed countries such as Japan, Denmark, Italy and France.

There are many traditional fish products in the world. Globalization, development of tourism, mutual interest to national cuisines spread exotic products on regional markets. Traditional dishes become more and more popular. Fish and fish products were traditionally considered as dietary and healthy products. Development of food markets and expanding geographical borders increase territory competiveness, potential of economic growth.

The manufacturing of fish products in the Republic of Buryatia in 2013 was 2200 ton. It is higher, than the manufacturing in 2012 by $4.8 \%$. It is necessary to notice the tendency of decreasing whitefish harvesting by $16.3 \%$ in 2013. Export of fish products increased in 2013 by $10 \%$, import decreased by $78.2 \%$. Therefore, it is important to study the consumption of fish products in Russia and the Republic of Buryatia.

\section{Literature Review}

Research of consumers' behavior studies the process by which individuals or groups of people select, buy, use, or dispose. It can be related to products, services, ideas, or experiences. People use all these to satisfy their needs and wants (Solomon, 2004). Different parameters can be used for these studies, including demographic characteristics such as age, sex, average income, marital status, profession, race, ethnicity, and education, etc.

Cluster analysis is widely used in economical science. It implies grouping block of data in the clusters by several indications.

The major idea of this method is to identify specific groups of individuals or objects that are similar to each other but different from individuals in other groups. Using cluster analysis can help to identify and describe the groups, which are most likely to buy some products. Based on different factors, cluster analysis is a good instrument to use for study the consumption, for example, of food products (Dolnicar S., 2003). 
Antokhonova I.V. (2005) and Nikiforova O.P. (2013) used cluster analysis to determine consumer preferences on the local food market. The consumption of different types of food products in Buryatia was studied. Primack B.A. et al (2012) described the groups of consumers of tobacco, marijuana, and alcohol among university students.

Many of researches were devoted to investigation of food consumption (Rivera D.Jr. et al., 2009; Corrêa Leite M.L. et al, 2003; Trocchia P.J. et al, 2003; Pouzauda F., 2010; Ryan I. et al, 2004). For instance, Trocchia P.J. et al., 2003 clusterized consumers using approach, based on factors such as vegetarian/meatarian orientation of respondents, as well as personal and demographic characteristics.

Therefore, the aim of research was identification of trends in fish products consumption in the Republic of Buryatia. The main focus of this research is to highlight aspects of consumption of fish and fish products in local economic market using cluster analysis, to develop a segmented scheme of consumers, based on their behavior along with personal and demographic characteristics. This approach will show similarity and difference in and between the groups.

\section{Materials and Methods}

The subjects of a study include 150 respondents, living in city of Ulan-Ude, Buryatia. Respondents were the heads of households. Data collection was primarily made via questionnaires in 2015. The questionnaire focused on frequencies and types of fish products. Also the consumption of fermented fish products was studied.

The fish consumption frequency questions measured most of the fish consuming frequencies. These questions several contained variants of answers: 1 . never or rarely, 2. once in several months, 3. once in several weeks, 4 . several times a week, 5. every day.

The information about consumption was collected with the use of quantitative questionnaire. Cluster analysis was used to separate the subjects of research. Study was based on the similarities in fish products consumption of consumers. A regression model, which included age, income, education, sex, was fitted to assess the major factors related to different fish consumption habits.

Cluster analysis was conducted with the use of application package Statistica 6.0 by Ward's method and k-means. For the research, a two-stage clustering approach was used. First stage included hierarchical cluster analysis with Ward's linkage. It was used to determine an appropriate number of groups. Second step included subsequent k-means cluster analysis. It was conducted to separate the data set into clusters, identified through the hierarchical clustering procedure.

\section{Results and Discussion}

Researchers collected 150 usable surveys. Five distinct clusters were derived after the analysis. The tree diagram of distribution of respondents by clusters is shown in Fig. 1.

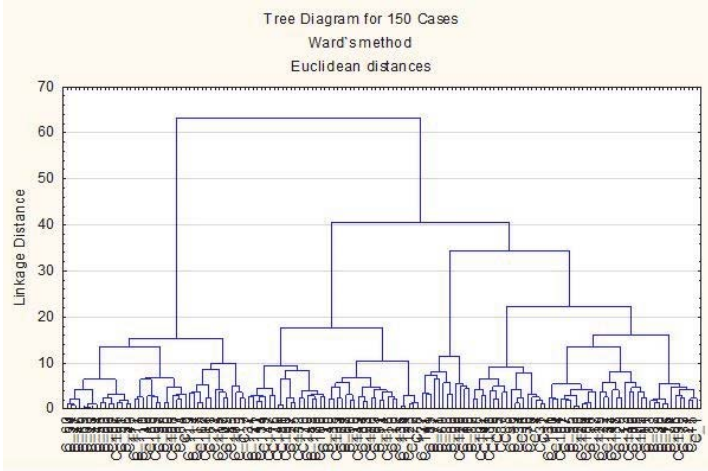

Figure 1. Tree of respondents distribution by clusters

Number of respondents in clusters was distributed the following way: 10,7\% of responded were presented in the first cluster, $37,3 \%$ - in 2nd cluster, $6 \%$ - in 3rd cluster , 32\% - in 4th cluster, 14\% - in 5th cluster. The average cash incomes in distinct clusters are shown in Fig.2. The lowest average income was in the fourth cluster, the highest were in second, third and fifth clusters. There wasn't significant difference between average incomes in these three clusters. 


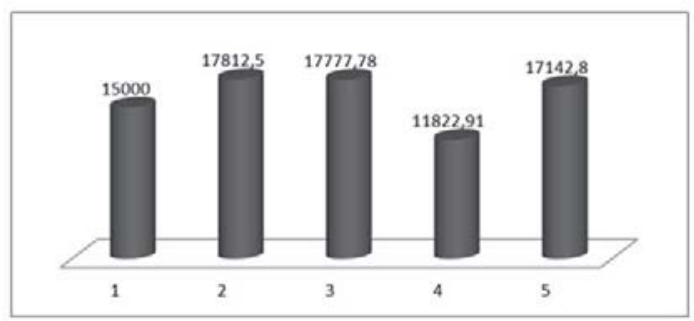

Figure 2. Average cash incomes by clusters, rubles in month

Demographic characteristics of the sample are presented below. Respondents were mostly young people under 40 with unfinished and finished higher education (Fig.3, Fig.4). Heads of households were mostly women (Fig.5).

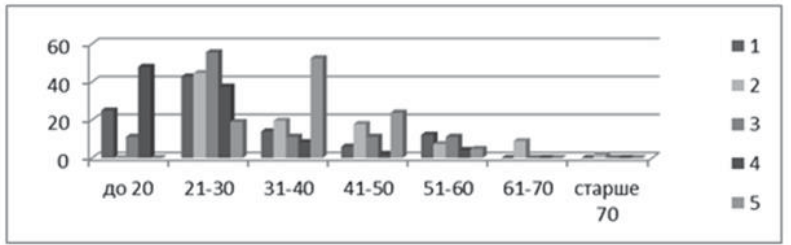

Figure 3. Division of respondents by age

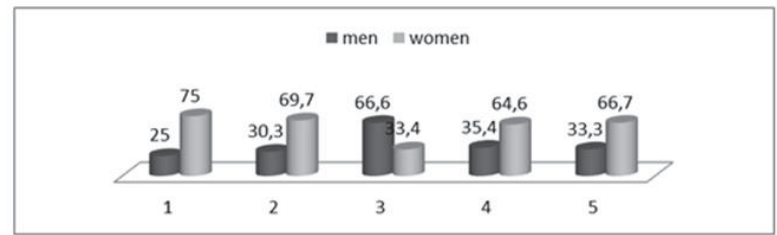

Figure 4. Division of respondents by sex

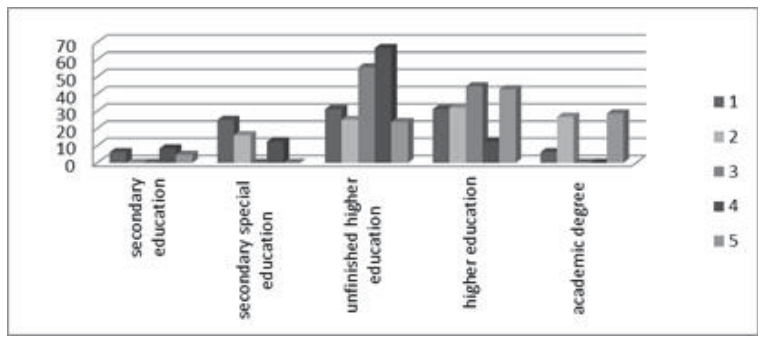

Figure 5. Division of respondents by level of education

Frequency of fish products consumption is shown in Fig.6. Almost all of the respondents consumed fish products. Just $5.3 \%$ of respondents in second cluster didn't consume its. The frequency of consuming differs by clusters. $18.75 \%$ respondents of first cluster, $28.6 \%$ of second cluster, $22.3 \%$ of third cluster, $14.6 \%$ of forth cluster, $19 \%$ of fifth cluster consume fish products several times a week. Consumption of fish products several times a month higher in firth cluster $76.2 \%$, lower in first cluster $-43.75 \% .37 .5 \%$ respondents of first cluster $37.5 \%$ respondents of first cluster, 14.3 - of second cluster, 22.2 - of third cluster, $22.9 \%$ - of forth cluster, 4.8 - of firth cluster consume fish products once in several months. 

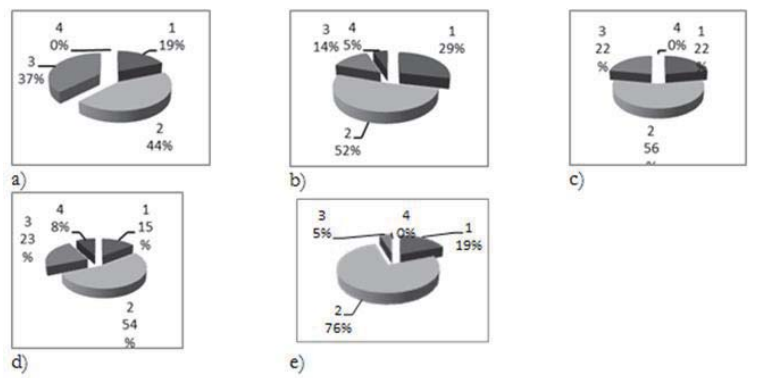

Figure 6. Frequency of fish products consumption by clusters (a - cluster № 1, b - cluster № 2, c - cluster № 3, d cluster № 4, e - cluster № 5)

The most valuable is fresh fish consumption, which preserve the useful properties and taste qualities for all age groups. $37,5 \%$ respondents of first cluster, $23,2 \%$ - of second cluster, $22,2 \%$ - of third cluster, $35,4 \%$ - of fourth cluster, $19 \%$ of firth cluster do not consume fresh fish regularly. $12.5 \%$ respondents of first cluster, $19.7 \%$ - of second cluster, $11.1 \%$ - of third cluster, $4.2 \%$ - of fourth cluster, $23.8 \%$ - of firth cluster consume fresh fish several times a week. Consumption several times a month higher in firth cluster ( $57.1 \%$ of respondents) (Fig. 7$)$.
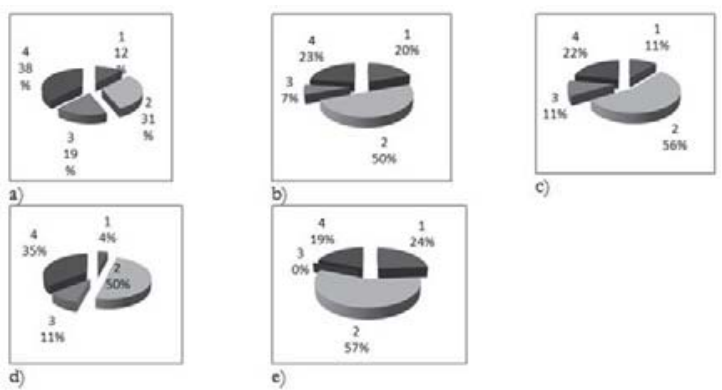

Figure 7. Frequency of fresh fish consumption by clusters ( $a$ - cluster № 1, b - cluster № 2, $c$ - cluster № 3, $d$ - cluster № 4, e - cluster № 5)

Salted fish takes the second place by percent of consumers. 31,25\% respondents of first cluster, $28,6 \%$ - second, $44.4 \%$ - third, $37.5 \%$ - forth, $14.3 \%$ - firth do not consume salted fish. Frequency of consumption several times a week higher in third and firth clusters $(22.3 \%, 23.8 \%)$, several times a month - in second and firth cluster $(53.6 \%, 61.9 \%)$ (Fig.8).

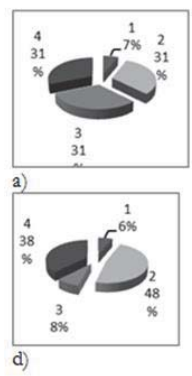

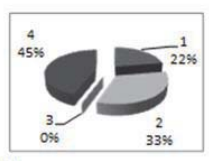

b)

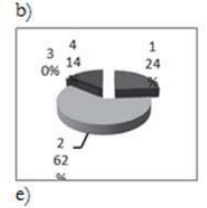

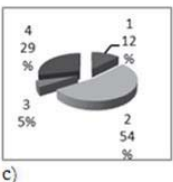

c)

Figure 8. Frequency of salted fish consumption by clusters (a - cluster № 1, b - cluster № 2, c - cluster № 3, d - cluster № 4, e - cluster № 5) 
Foods have been smoked by humans throughout history. Originally this was done as a preservative. Smoked fish is not as popular as salted fish in the Republic of Buryatia. $56.25 \%$ of respondents in first cluster, $64.3 \%$ - in second, $66.6 \%$ in third, $70.8 \%$ - in fourth, $57.1 \%$ - in fifth cluster do not consume cured fish. The consumption several times a month vary from 11.1 to $28.6 \%$.
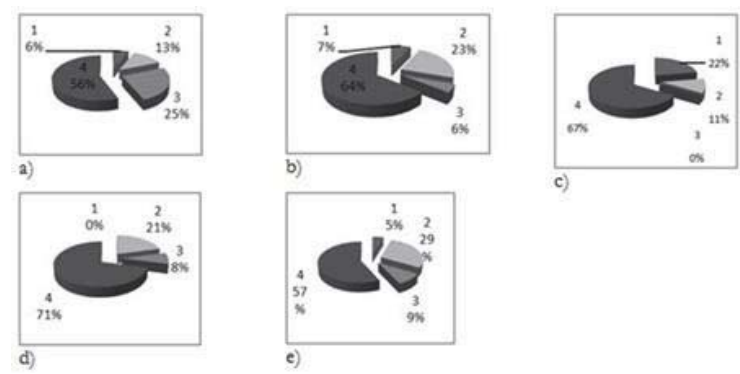

Figure 9. Frequency of cured fish consumption by clusters (a - cluster № 1, b - cluster № 2, c - cluster № 3, d - cluster № 4, e - cluster № 5)

Consumption of dried fish is not high, first cluster is leading by this indicator. This type of product is oriented on specific segment.
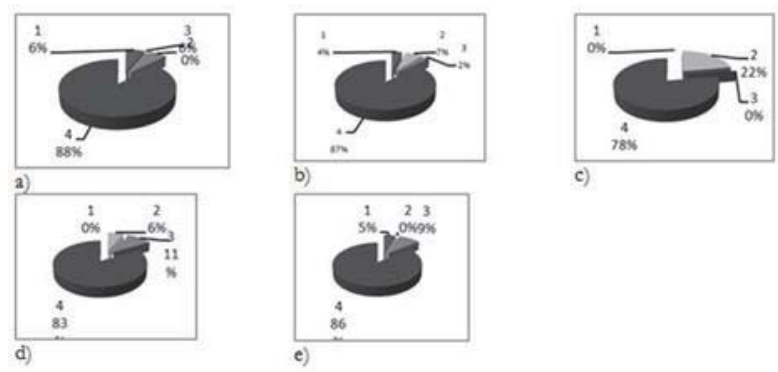

Figure 10. Frequency of dried fish consumption by clusters ( $a$ - cluster № 1, b - cluster № 2, c - cluster № 3, d - cluster № 4, e - cluster № 5)

Canned fish cannot be identified as main food products. The main advantage of canned fish is its long shelf life. It is considered mainly as ingredient of complex dishes. Respondents of fourth cluster consume canned fish more frequently.
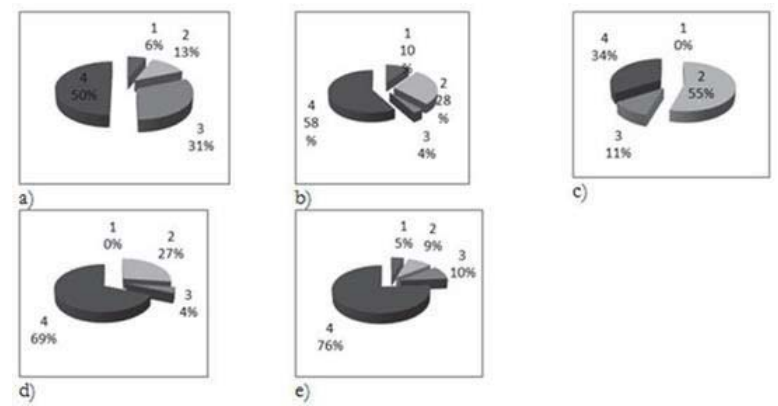

Figure 11. Frequency of canned fish consumption by clusters (a - cluster № 1, b - cluster № 2, c - cluster № 3, d cluster № 4, e - cluster № 5) 
Also there is a type of fish product like fermented fish. Fermented fish is a traditional food in European and Asian cuisines. This production relies both on naturally occurring enzymes (in the muscle or the intestinal tract) as well as bacteria (Skåra T. et al. (2015)). Also there is fermented fish product made of Baikal omul in the Republic of Buryatia.

Baikal omul has a definite place in the structure of nutrition of the population of Baikal region. It should also be noticed that the Baikal omul is not only a delicacy but also a brand of Lake Baikal. Baikal omul is well known in Russia and worldwide. It is believed that Baikal omul has a special taste. There is also special type of product - omul "s dushkom". This product is a delicacy and a traditional dish of people, who live in Baikal region. It is the most widely consumed in Kabansk and Barguzin region of the Republic of Buryatia. Omul 's dushkom' has specific technology of manufacturing (Nikiforova A.P., Nikiforov P.G., 2015; Nikiforova A.P., Nikiforova O.P., 2015).

Like fermented fish products of other countries, omul 's dushkom' has a unique taste and flavor due to changes, taken place during fermentation process. Enzymes that are already present in fish together with microorganisms are responsible for the fermentation process. The result of this process is hydrolysis of the fish proteins, which lead to production of free amino acids, fatty acids, peptides. This product is a very good source of proteins and lipids (Nikiforova A.P., Nikiforov P.G., 2015; Nikiforova A.P., Nikiforova O.P., 2015).

According to the survey the majority of respondents are familiar with fermented fish products. $31.25 \%$ respondents of first cluster, $48.2 \%$ - second, $55.1 \%$ - third, $43.75 \%$ - forth, $38.1 \%$ would like to buy "omul with odour" processed at fish processing plants..

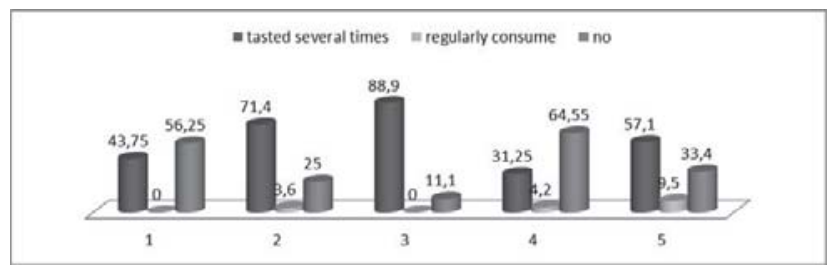

Figure 12. Cluster separation by answers on question "Did you taste "omul with odour"?"

\section{Conclusion}

As reported above, the consumers were separated into five clusters in the study. The main characteristics of each cluster are described below.

Cluster № 1: Approximately ten percent of respondents belong to this cluster. This group is comprised of the most conservative, less-progressive consumers with low income. This cluster doesn't have the growth potential.

Cluster № 2: $37,3 \%$ of respondents belongs to the second cluster. This cluster contains high percent of young people with higher education and relatively high level of income, working as specialists. The respondents of this group actively include new dishes in their diets, which is possibly related to high tourist activity of this group. According to the survey, demand on fish products higher in this cluster. This cohort tends to increase, therefore demand has potential.

Cluster № 3: This cluster is the smallest. It includes $6 \%$ of a sample. Cluster members are predominantly males who can be characterized as gourmets.

Cluster № 4: Representatives of economy class comprise the largest cluster (32\% of respondents). This group consists of less-educated people with low income. Price of fish has a great meaning for members of this cluster. They mainly guided by price of fish.

Cluster № 5: Educated consumers, which consume mostly health food comprise $14 \%$ of the sample. This group consists of highly educated women, preferring to have fish in their diet. This group has a growth potential.

One of the issues studied in this work is the consumption of traditional fermented fish products. It was shown, that the overwhelming majority of respondents are familiar with fermented fish products, however, professional information about product should be provided. However, just several respondents consume "omul with odour" regularly. The respondents causes preventing the consumption are odour and fear of food poisoning. $55.5 \%$ respondents of third cluster and $48.2 \%$ of second cluster wish to buy the fermented product.

Therefore, it is possible to highlight a target public of fermented product. For promotion of production it is necessary to consider the wishes of customers to organoleptic parameters and appearance. Certification of production allows to proof its health security, promote it to other regions. Branding and promotion of "omul with odour" in our view can increase public awareness about Republic of Buryatia, interest probable investors. 


\section{Acknowledgement}

This work was supported by a grant of the President of Russian Federation for young Russian scientists (MK2752.2015.4)

\section{References}

Antokhonova I. (2005) The problems of consumers demand evolution in the transition economies of the region. Studies on Russian Economic Development, 2, 111-117.

Corrêa Leite M.L., Nicolosi A., Cristina S., Hauser W.A., Pugliese P. and Nappi G. Dietary and nutritional patterns in an elderly rural population in Northern and Southern Italy: (I). (2003) A cluster analysis of food consumption//European Journal of Clinical Nutrition 57, 1514-1521. doi:10.1038/sj.ejcn.1601719

Dolnicar S. (2003) Using cluster analysis for market segmentation - typical misconceptions, established methodological weaknesses and some recommendations for improvement // Australasian Journal of Market Research, 11(2), p. 5-12.

Nikiforova A., Nikiforova O. (2015) Traditional fermented fish products in Northern regions: review I/ Arctic Dialogue in the Global World: Proceedings of the Joint Science and Education Conference. - Ulan-Ude: Buryat State University Publishing Department, P. 330331.

Nikiforova A.P., Nikiforov P.G. (2015) The issue on the development of fermented omul technology // Materials of XII international scientific practical conference "Food. Ecology. Quality". Novosibirsk.10-13 (in russian).

Nikiforova O.P. (2013) The study of consumer preferences on the local food market. The proceedings of scientific conference in Economics. - Ulan-Ude: ESSUTM, P. 38-44 (in russian).

Pouzauda F., Ibboua A., Blanchemanchea S., Grandjeanb P., Krempfc M., Philipped H.J. and Vergera P. (2010) Use of advanced cluster analysis to characterize fish consumption patterns and methylmercury dietary exposures from fish and other sea foods among pregnant women // Journal of Exposure Science and Environmental Epidemiology 20, 54-68.

Primack B.A., Kim K.H., Shensa A., Sidani J.E., Barnett T.E., Switzer G.E.(2012) Tobacco, Marijuana, and Alcohol Use in University Students: A Cluster Analysis // Journal of American College Health, 60:5, 374-386.

Rivera D.Jr., Burleyb H., Adams C. (2009) A Cluster Analysis of Young Adult College Students' Beef Consumption Behavior Using the Constructs of a Proposed Modified Model of Planned Behavior// Journal of Food Products Marketing. Volume 16, Issue 1.

Ryan I. , Cowan C.,McCarthy M., O'sullivan C. (2004) Segmenting Irish Food Consumers Using the Food-Related Lifestyle Instrument, Journal of International Food \& Agribusiness Marketing, 16:1, 89-114.

Skåra T., Axelsson L., Stefansson G., Ekstrand B., Hagen H. (2015) Fermented and ripened fish products in the northern European countries. Journal of Ethnic Foods, 2, 18-24.

Solomon M. R. (2004). Consumer behavior: Buying, having, and being (6th ed.). Upper Saddle River, NJ: Prentice Hall.

Trocchia P.J. \& Janda S.(2003) A Cluster Analytic Approach for Consumer Segmentation Using the Vegetarian/Meatarian Distinction, Journal of Food Products Marketing, 9:2, 11-23. 